\title{
Modifikasi Alat Pencetak Dangke Dalam Meningkatkan Kualitas dan Produktivitas Produk Dangke
}

\section{Modification Of Dangke Printing Tools In Improving Quality And Productivity Of Dangke Products}

\author{
Muh. Warid Yasir, Program Studi Pendidikan Teknologi Pertanian Fakultas Teknik, \\ Universitas Negeri Makassar. Email : Waridyasir29@gmail.com \\ Mohammad Wijaya, Program Studi Pendidikan Teknologi Pertanian Fakultas Teknik, \\ Universitas Negeri Makassar. Email : \\ Jamaluddin, Program Studi Pendidikan Teknologi Pertanian Fakultas Teknik, Universitas \\ Negeri Makassar. Email :
}

\begin{abstract}
Abstrak
Penelitian ini bertujuan untuk memodifikasi cetakan yang dapat diterapkan pada pembuatan dangke dan mengetahui efisiensi alat hasil rancangan. Bentuk penelitian ini adalah modifikasi alat. Data penelitian diperoleh dari hasil pengujian dengan melakukan uji coba perbandingan antara pencetakan manual dan menggunakan alat yang telah dimodifikasi. Teknik analisis data dilakukan secara kuantitatif dengan statistik deskriftif. Prinsip kerja dari alat ini adalah dengan sistem pengepresan, dalam satu kali pencetakan dihasilkan dua buah dangke. Hasil penelitian ini menujukkan bahwa dengan menggunakan alat proses pencetakan dangke relatif lebih cepat dan mudah dibandingkan dengan cetakan manual.
\end{abstract}

Kata Kunci: Modifikasi, Pencetak, Dangke

\begin{abstract}
This study aims to modify the mold that can be applied to the production of dangke and knowing the efficiency of tool design result. The form of this research is tool modification. Research data obtained from the testing results by conducting a comparison test between manual printing and using a modified tool. Data analysis techniques are carried out quantitatively with descriptive statistics. The working principle of this tool is the pressing system, one time printing process produces two pieces dangke. The results of this study show that using the printing process tool can be relatively faster and easier compared manual printing.
\end{abstract}

Keywords: Modification Printing, Dangke

\section{Latar Belakang}

Perkembangan ilmu pengetahuan dan teknologi pada saat ini begitu pesat mengikuti perubahan zaman. Teknologi membuat segala sesuatu yang dilakukan agar menjadi lebih mudah. Manusia dituntut untuk melakukan pemikiranpemikiran yang inovatif sehingga dapat mengimbangi perubahan teknologi yang semakin berkembang.

Manusia selalu berusaha untuk menciptakan sesuatu yang dapat mempermudah aktivitasnya, hal inilah yang mendorong perkembangan teknologi yang telah banyak menghasilkan alat untuk mempermudah kegiatan manusia bahkan menggantikan peran manusia dalam suatu fungsi tertentu. Namun perkembangan 
tersebut belum terlihat di bidang industri rumah tangga (home industry) pembuatan dangke. Dangke merupakan makanan tradisional khas Kabupaten Enrekang yang dibuat dengan bahan dasar susu segar dari kerbau atau sapi yang digumpalkan dengan menambahkan getah pepaya. Proses pembuatan dangke kurang mendapat perhatian dalam pengembangannya sehingga produk ini kurang dikenal. Pada hal produk ini memiliki potensi besar untuk menjadi salah satu sumber protein hewani (Rahman, 2013). Sehingga peneliti mengemukakan ide untuk mengembangkan alat pencetak dangke. Alat ini dapat digunakan pada proses pembuatan dangke.

Dangke adalah sejenis keju yang memiliki tampilan dan tekstur seperti tahu yang berwarna putih hingga kekuningan. Selain memiliki nilai gizi yang tinggi, produk olahan susu ini disukai oleh masyarakat kabupaten Enrekang. Makanan khas ini diproduksi melalui proses pemanasan susu yang ditambahkan getah papaya sehingga membentuk gumpalan kemudian dicetak sehingga membentuk tekstur dangke yang lebih kompak. Berdasarkan jumlah air yang terkandung di dalamnya, dangke termasuk dalam golongan keju lunak (soft cheese) dengan kadar air sebesar $45,75 \%$ berwarna putih dan bersifat elastis (Rahman, 2013).

Berdasarkan hasil observasi yang telah dilakukan di Desa Baba, Kecamatan Cendana, Kabupaten Enrekang, saat ini proses pembuatan dangke di kalangan masyarakat masih sangat sederhana, khususnya pada proses pencetakan. Cetakan yang digunakan oleh masyarakat dalam pembuatan dangke adalah tempurung kelapa. Susu yang dihasilkan para peternak tidak mampu diolah sekaligus menjadi dangke, karena dalam proses pencetakannya membutuhkan waktu yang lama dan tenaga yang banyak sehingga masyarakat kewalahan dalam mencetak dangke. Proses pencetakan gumpalan harus dalam kondisi panas agar satu sama lainnya dapat melekat sehingga tekstur dangke menjadi padat dan kompak. Selain itu, susu juga tidak dapat bertahan lama sehingga harus diolah secepatnya. Menurut Oka, dkk. (2017) salah satu faktor yang sangat menentukan kualitas susu dan arah pengembangannya adalah kandungan kimia susu. Sebagaian susu yang dihasilkan peternak yang tidak mampu diolah menjadi dangke dijual dalam bentuk susu segar sehingga mempengaruhi nilai jualnya. Susu yang dijual tanpa diolah menjadi dangke memiliki harga yang lebih murah dibandingkan dengan harga susu yang telah diolah menjadi dangke. Untuk mempercepat produksi dangke diperlukan alat yang dapat memudahkan dalam proses pencetakan.

Upaya untuk mengatasi masalah diatas adalah melakukan pengembangan alat dengan memodifikasi alat cetak dan press tahu menjadi alat pencetak dangke. Salah satu bagian yang akan diubah yaitu cetakan dari bentuk persegi menjadi setengah elips atau menyerupai bentuk setengah tempurung kelapa yang berfungsi sebagai cetakan dangke dengan prinsip kerja yang sama yaitu sistem pengepresan. Mencetak merupakan penentu utama proses pembuatan dangke yang bermutu. Diharapkan dengan adanya alat ini proses produksi dangke lebih cepat dan lebih muda serta dangke yang dihasilkan ukurannya seragam.

\section{Tujuan Penelitian}

Tujuan yang ingin dicapai dalam penelitian ini adalah:

1. Untuk mengetahui cara membuat alat pencetak dangke.

2. Untuk mengetahui uji kinerja alat pencetak dangke hasil rancangan.

\section{Bahan dan Metode}

Metode yang digunakan pada penelitian ini adalah penelitian rekayasa atau rancang bangun, pada penelitian ini 
dilakukan pengujian kinerja alat pencetak dangke.

\section{Waktu}

Penelitian ini dilakukan selama 3 bulan dengan persiapan penelitian meliputi persiapan komponen dan peralatan penunjang, persiapan penelitian lanjutan meliputi persiapan bahan serta keperluan pengambilan data.

\section{Tempat}

Penelitian ini dilakukan di Laboratorium Program Studi Pendidikan Teknologi Pertanian Fakultas Teknik Universitas Negeri Makassar.

\section{Alat dan Bahan}

Alat dalam penelitian ini adalah (1) aplikasi sketchup 2016 pro, (2) mesin las, (3) mesin bor, (4) mesin gerinda, (5) roll meter, (6) palu, (7) mistar siku, dan (8) tang. Sedangkan bahan yang digunakan adalah (1) baja holo, (2) besi nako, (3) seng plat, (4) plat strip, (5) pipa besi, (6) elektroda, (7) baut dan mur, (9) cat, (10) susu sapi.

\section{Prosedur Rancang Bangun}

1. Pembuatan rangka utama dibuat dari besi holo dengan ukuran panjang rangka $600 \mathrm{~mm}$, tinggi rangka $500 \mathrm{~mm}$ dan lebar $400 \mathrm{~mm}$. Menurut Asrianto, dkk. (2018) rangka berfungsi untuk memperkokoh alat dan untuk menopang komponen alat.

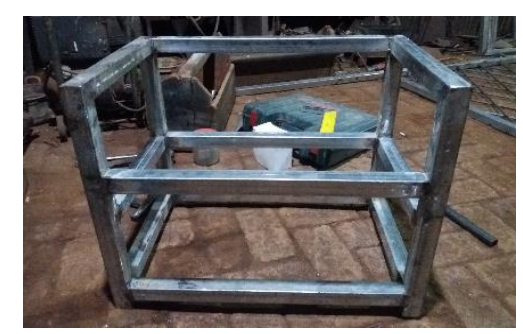

Gambar 1

Hasil pembuatan rangka
2. Pembuatan penekan dibuat dengan bahan besi pipa, plat strip, besi nako dan besi kotak. Penekan terdiri dari beberapa bagian diantaranya, tiang utama dengan ukuran $550 \mathrm{~mm}$, tiang pendorong 500 $\mathrm{mm}$, pemadat panjang $360 \mathrm{~mm}$ dan tuas $270 \mathrm{~mm}$. Untuk bagian bawah pemadat dipasang besi pipa dengan cara dilas, berdiameter $70 \mathrm{~mm}$ dan panjang $25 \mathrm{~mm}$. Tahap pengelasan dilakukan untuk menguatkan tiap sambungan (Arhamsyah, dkk. 2018).

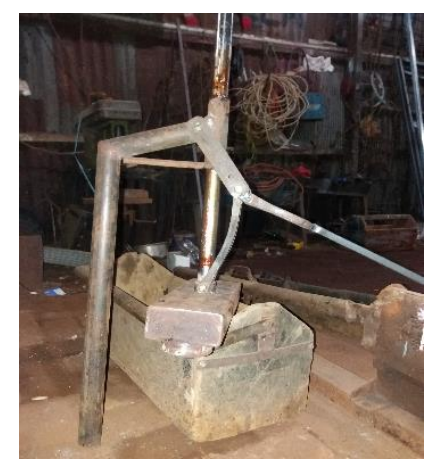

Gambar 2. Penekan

3. Cetakan memiliki ukuran diameter 72 $\mathrm{mm}$, tinggi $100 \mathrm{~mm}$ dibuat dari plat jenis galvanis ketebalan $0.9 \mathrm{~mm}$.

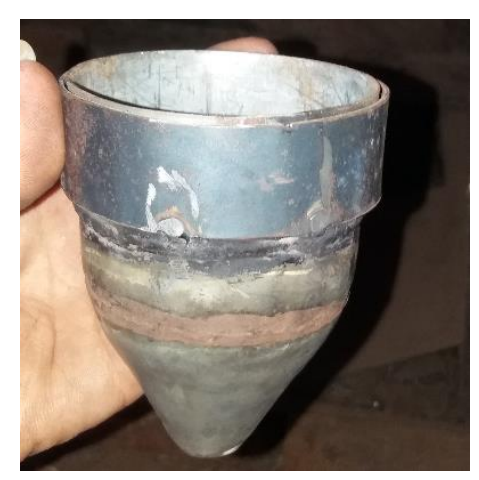

Gambar 3. Cetakan

4. Dudukan cetakan memiliki ukuran panjang $520 \mathrm{~mm}$, lebar $300 \mathrm{~mm}$ dan diameter lubang $73 \mathrm{~mm}$, terbuat dari besi plat ketebalan $3 \mathrm{~mm}$. 


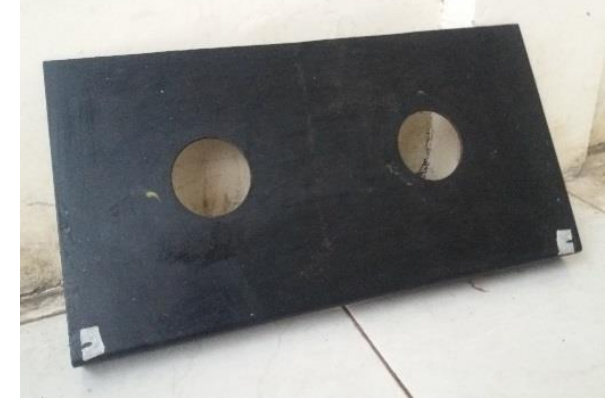

Gambar 4 Dudukan cetakan

5. Casing memiliki ukuran panjang keseluruhan $1400 \mathrm{~mm}$ dan tinggi 480 $\mathrm{mm}$, terbuat dari seng plat. Casing berfungsi untuk menutupi rangka bagian samping dan belakang sehingga air person dangke tidak menyebar.

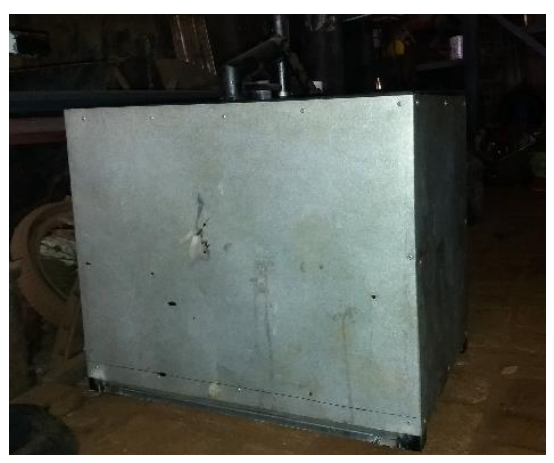

Gambar 5. Pemasangan casing

\section{Uji Coba Produk}

1. Lakukan pengecekan terlebih dahulu pada alat pencetak.

2. Bersihkan alat khususnya pada bagian pemadat dan cetakan

3. Menyiapkan alat dan bahan seperti panci, sendok, tepisan santan susu segar, dan getah papaya untuk membuat dangke.

4. Membuat dangke dengan cara memanaskan susu sapi dan menambahkan getah papaya, diaduk hingga terbentuk gumpalan

5. Mengurangi air yang tercampur dengan gumpalan

6. Stopwatch mulai dihidupkan saat cetakan mulai diisi

7. Masukkan gumpalan ke dalam cetakan, kedua cetakan diisi penuh.
8. Letakkan kedua cetakan di masingmasing lubang pada dudukan kemudian didorong masuk

9. Secara perlahan tuas ditekan sampai bagian pemadat rapat pada permukaan cetakan, air perasan keluar pada lubang yang terdapat pada bagian bawah cetakan.

10. Tuas ditarik ketika air perasaan tidak lagi menetes, kedua cetakan diangkat keluar dari dudukan.

11. Lihat pada stopwatch berapa lama waktu yang digunakan mulai dari memasukkan gumpalan sampai kedua cetakan diangkat dari dudukan.

\section{Teknik Analisa Data}

Teknik analisis data yang digunakan pada penelitian ini adalah teknik analisis data kuantitatif dengan statistik deskriktif, data yang diperoleh ditabulasikan ke dalam bentuk tabel kemudian akan menjadi acuan dalam pembuatan deskripsi mengenai uji kinerja alat. Pengujian pada penelitian ini hanya terbatas pada uji alat, sehingga data yang disajikan dalam penelitin ini adalah bentuk rasio yang diperoleh dari hasil uji coba.

\section{Hasil dan Pembahasan}

\section{A. Hasil Perancangan Alat}

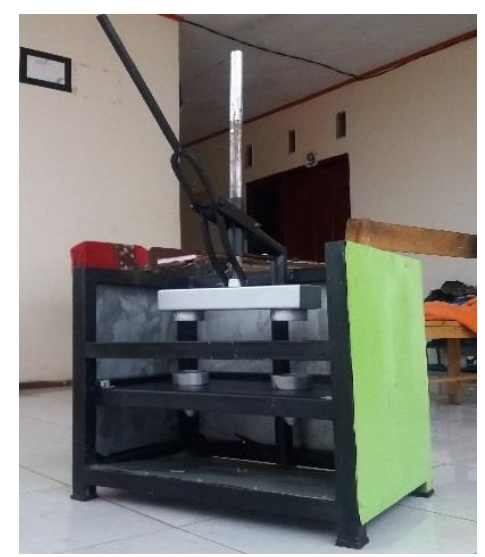

Gambar 6. Alat pencetak dangke 


\section{B. Hasil Uji Coba Alat}

Berikut tabel yang menunjukkan hasil pengujian secara manual dan menggunakan alat.

Tabel 1. Hasil Uji Coba Cetakan Manual

\begin{tabular}{cccc}
\hline Percobaan & $\begin{array}{c}\text { Waktu } \\
\text { (detik) }\end{array}$ & Hasil & $\begin{array}{c}\text { Berat } \\
(\mathrm{g}) / \text { dangke }\end{array}$ \\
\hline 1 & 304 & 1 buah & 234 \\
\hline 2 & 308 & 1 buah & 231 \\
\hline 3 & 314 & 1 buah & 236 \\
\hline Rata-rata & 309 & 1 & 234 \\
\hline
\end{tabular}

Berdasarkan hasil pengujian menggunakan cetakan manual dalam proses pencetakan dangke waktu yang digunakan pada percobaan pertama yaitu 304 detik dihasilkan 1 buah dangke, untuk percobaan kedua waktu yang digunakan yaitu 308 detik dihasilkan 1 buah dangke dan percobaan ketiga waktu yang digunakan yaitui 314 detik dihasilkan 1 buah dangke. Sehingga dalam 1 kali pencetakan dangke rata-rata waktu yang digunakan adalah 309 detik dan rata-rata berat 1 buah dangke yang dihasilkan adalah $234 \mathrm{~g}$ (Tabel 1).

\begin{tabular}{cccc}
\multicolumn{4}{c}{ Tabel 2 Hasil Uji Coba Alat pencetak } \\
\hline Percobaan & $\begin{array}{c}\text { Waktu } \\
\text { (detik) }\end{array}$ & Hasil & $\begin{array}{c}\text { Berat } \\
\text { (g)/dangke }\end{array}$ \\
\hline 1 & 223 & 2 buah & 225 \\
\hline 2 & 218 & 2 buah & 224 \\
\hline 3 & 215 & 2 buah & 225 \\
\hline Rata-rata & 218 & 2 & 224 \\
\hline
\end{tabular}

Berdasarkan hasil uji coba alat dalam proses pencetakan dangke waktu yang digunakan pada percobaan pertama yaitu 223 detik dihasilkan 2 buah dangke, untuk percobaan kedua waktu yang digunakan yaitu 218 detik dihasilkan 2 buah dangke dan percobaan ketiga waktu yang digunakan yaitu 215 detik dihasilkan 2 buah dangke. Sehingga dalam satu kali pencetakan rata-rata waktu yang digunakan yaitu 218 detik dihasilkan 2 buah dangke dan berat rata-rata 1 buah dangke yang dihasilkan adalah 224 gram.

Berikut table hasil uji tingkat kesukaan responden terhadap sifat fisik dangke.

Tabel 3. Hasil Penilaian Tingkat Kesukaan Tekstur Dangke

\begin{tabular}{ccc}
\hline \multirow{2}{*}{ Tekstur } & \multicolumn{2}{c}{ Jenis Dangke } \\
\cline { 2 - 3 } & Manual & Alat \\
\hline Halus & 5 & 4 \\
Agak halus & - & 1 \\
\hline
\end{tabular}

Hasil penilaian terhadap tekstur dangke (Tabel 3) dengan cetakan manual menunjukkan bahwa 5 orang responden memilih halus, sedangkan tekstur dangke hasil cetakan menggunakan alat 4 orang memilih halus dan 1 orang memilih agak halus. Berdasarkan hasil penilaian responden menunjukkan bahwa dangke hasil cetakan secara manual memiliki tekstur lebih halus dibanding dangke dengan cetakan menggunakan alat.

Hal tersebut menandakan bahwa dangke yang dihasilkan dengan menggunakan cetakan manual lebih padat karena dalam proses pencetakan dilakukan dengan cara menambahkan sedikit demi sedikit gumpalan ke dalam cetakan sambil ditekan-tekan dengan sendok sehingga gumpalan saling menyatu dan hasilnya lebih kompak dan padat. Sedangkan dangke hasil cetakan menggunakan alat memiliki tekstur kurang halus karena dalam proses pencetakan langkah penekan dibatasi dan pendek sehingga gumpalan kurang padat. Jadi untuk menghasilkan gumpalan yang lebih padat dan kompak sebaiknya langkah penekan dibuat lebih panjang sehingga didapatkan tekstur dangke yang halus. 
Tabel 4. Hasil Penilaian Tingkat Kesukaan Bentuk Dangke

\begin{tabular}{ccc}
\hline \multirow{2}{*}{ Bentuk } & \multicolumn{2}{c}{ Jenis Dangke } \\
\cline { 2 - 3 } & Manual & Alat \\
\hline Sangat Suka & 5 & 3 \\
Suka & - & 2 \\
\hline
\end{tabular}

Hasil penilaian terhadap bentuk dangke hasil cetakan menunjukkan bahwa 5 orang responden sangat menyukai bentuk dangke dengan cetakan manual, sedangkan untuk hasil dari penggunaan alat 3 orang sangat menyukai bentuk dangke dan 2 orang hanya menyukai bentuk dangke hasil cetakan menggunakan alat. Kedua cetakan yang digunakan baik cetakan manual dan cetakan yang dibuat memiliki bentuk yang sama. Berdasarkan hasil penilaian menunjukkan bahwa responden masih lebih menyukai bentuk dangke hasil cetakan manual.

Dangke mempunyai keistimewaan sebagai produk tradisional sehingga kekhasan produk ini merupakan konstributor nilai tambah terbesar dangke. Dengan demikian, karakteristik dangke perlu dipertahankan bukan hanya dari segi warna, rasa, tekstur dan aroma namun juga bentuk dangke (Fitrah, 2012). Sebuah penelitian yang dilakukan oleh JICA (2009), menunjukkan bahwa sebagian besar pedagang pada dua pasar tradisional di Kabupaten Enrekang (pasar Cakke dan Sudu) mengaku dangke yang dikemas selain menggunakan daun pisang dan dangke yang dicetak dalam bentuk kotak kurang diminati oleh pelanggan.

\section{Simpulan}

Berdasarkan dari hasil penelitian modifikasi alat pencetak dangke dalam meningkatan kualitas dan produktivitas produk dangke, dapat ditarik kesimpulan sebagai berikut :
Proses modifikasi alat pencetak dangke dalam meningkatkan kualitas dan produktivitas produk dangke melalui beberapa tahap diantaranya pembuatan rangka, pembuatan penekan, pembuatan cetakan, pembuatan dudukan, pemasangan semua komponen, pemasangan casing dan terakhir pengecatan casing.

Dalam satu kali pencetakan dengan menggunakan alat dihasilkan 2 buah dangke sedangkan cetakan manual dihasilkan 1 buah dangke, sehingga waktu yang digunakan dalam proses pencetakan relatif lebih cepat dibandingkan dengan cetakan manual, namun dari segi tekstur dan bentuk dangke hasil cetakan manual lebih disukai responden dibanding dangke hasil cetakan menggunakan alat.

\section{Daftar Pustaka}

Arhamsyah, H. Syam, dan Jamaluddin. 2018. Modifikasi mesin penggering dengan memanfaatkan udara panas dari elemen pemanas listrik. Jurnal Pendidikan Teknologi Pertanian. Vol. 4 : S196-S208.

Asrianto, Jamaluddin, dan Kadirman. 2018. Modifikasi Mesin Pengering BijiBijian dengan Bahan Bakar Tempurung Kelapa. Jurnal Pendidikan Teknologi Pertanian. Vol. 4 : S222-S231.

Fitrah, Isyana. 2012. Studi Tingkat Higiene dan Cemaran Bakteri Salmonella Sp pada Pembuatan Dangke Susu Sapi di Kecamatan Cendana Kabupaten Enrekang. Skripsi. Makassar: Fakultas Peternakan Universitas Hasanuddin

Japan International Cooperation Agency (JICA), 2009. Laporan Hasil Kegiatan: Identifikasi dan Kajian Komoditi Utama Propinsi Sulawesi Selatan: Komoditas Susu. JICA dan UNHAS. Makassar. 
JPTP Jurnal Pendidikan Teknologi Pertanian

Oka, B., M. Wijaya, dan Kadirman. 2017. Karakteristik Kimia Susu Sapi Perah di Kabupaten Sinjai. Jurnal Pendidikan Teknologi Pertanian. Vol. 3 : 195-202.

Rahman, S. 2013. Studi Pengembangan Dangke sebagai Pangan Lokal Unggulan dari Susu di Kabupaten Enrekang. Jurnal Aplikasi Teknologi Pangan 3 (2) Indonesian Food Technologists. 